\title{
Sociedade civil e institucionalização da intermediação: Brokers diferentes, dilemas semelhantes'
}

\author{
Adrian Gurza Lavalle \\ Marisa von Bülow
}

\section{Resumo}

A intermediação é inerente à mobilização social, porque as tarefas de coordenação de atores mobilizados não podem ser realizadas sem intermediários - sejam eles informais ou institucionalizados. Contudo, a intermediação institucionalizada no âmbito da sociedade civil tem recebido pouca atenção. Este artigo analisa conceitualmente o papel de organizações cuja função é exercer papéis de intermediação entre atores da sociedade civil e entre estes e outros tipos de atores. $\mathrm{O}$ texto propõe uma definição desses brokers e desenvolve uma tipologia com intuito duplo: avançar na compreensão das diversas modalidades de intermediação institucionalizada e na análise dos dilemas associados à criação de organizações encarregadas de diferentes papéis de intermediação. Com base em trabalhos de pesquisa anteriores e como um exercício de aplicação da tipologia, o artigo também oferece uma análise empírica da atuação de brokers institucionalizados e suas mudanças ao longo do tempo.

Palavras-chave: Broker. Intermediários. Sociedade civil. Movimentos sociais. Intermediação.

1 Os nomes dos autores aparecem em ordem alfabética, tendo ambos contribuido igualmente para este artigo. Marisa von Bülow agradece o apoio do Projeto do Núcleo Milênio NS 1000 I 4 e o Projeto Fondecyt no I I30897 do CONICYT Chile. Adrian Gurza Lavalle agradece o Institute for European Studies e o Centre for the Study of Democratic Institutions, ambos da Universidade de British Columbia, bem como o auxilio 20 /2/I8439-6 da Fundação de Amparo à Pesquisa do Estado de São Paulo (FAPESP). Também agradece o financiamento do Centro de Estudos da Metrópole (CEBRAP, USP), processo n 20/3/076/6-7. Fundação de Amparo à Pesquisa do Estado de São Paulo (FAPESP). As opiniões, hipóteses e conclusões ou recomendações expressas são de responsabilidade dos autores e não necessariamente refletem a visão da FAPESP. Os dois autores agradecem a Federico Rossi e Margaret Keck por comentários sobre versões anteriores deste texto, bem como os comentários recebidos durante o IV Seminário Nacional do Núcleo de Pesquisa sobre Movimentos Sociais da Universidade Federal de Santa Cartarina (NPMS-UFSC) e aqueles emitidos pelos pareceristas anônimos.

2 Professor do Departamento de Ciência Politica da Universidade de São Paulo (USP). Pesquisador do Centro de Estudos da Metrópole (CEM). Pesquisador do Centro Brasileiro de Análise e Planejamento (CEBRAP). Email: gurzalavalleadrian@gmail.com.

3 Professora do Instituto de Ciência Politica da Universidade de Brasília (UnB).Pesquisadora da Pontificia Universidad Católica de Chile. Email: marisavonbulow@gmail.com. 


\section{Introdução}

A intermediação é inerente à mobilizaçâo social porque as tarefas de coordenação de atores mobilizados não podem ser realizadas sem papéis de intermediação e seus atores: os brokers ou intermediadores. Nosso conhecimento sobre esses atores na sociedade civil é, todavia, limitado. Os avanços produzidos nos últimos anos na literatura de movimentos sociais ainda não permitem compreender a variação de modalidades de intermediaçáo, nem extrair consequências analíticas mais gerais dessa variação, pois tendem a atribuir a diferentes tipos de brokers funçóes e efeitos semelhantes. Os intermediários são atores fundamentais na ação coletiva, é claro, mas seus papéis e impactos variam consideravelmente. Văo desde iniciativas muito informais de intermediaçáo até as altamente institucionalizadas, e de formas extremamente eficazes a formas de eficácia duvidosa ou nula. Mais: brokers podem cumprir papéis de intermediaçáo interna, no seio de constelaçóes e atores da sociedade civil com fortes afinidades, e/ou externa, na forma de pontes com outros conjuntos de atores na sociedade civil, no Estado ou no mercado.

Este artigo ${ }^{4}$ procura contribuir para o recente aumento do interesse no estudo dos brokers na literatura sobre movimentos sociais, apresentando uma análise direcionada a formas institucionalizadas de intermediaçáo (brokerage), que, surpreendentemente, têm recebido pouca atençâo sistemática. Intermediários informais e institucionalizados diferem em aspectos cruciais. Os primeiros desempenham seu papel circunstancialmente em virtude de sua posição e trajetória no campo dos atores em questão, de suas características e de fatores conjunturais, mas náo foram criados para o exercício de tais papéis nem, por conseguinte, obedecem a um mandato que, em princípio, os vincule e subordine a outros atores - e tampouco recebem deles delegaçáo ou autorização expressa.

Os brokers institucionalizados são entendidos aqui como organizações criadas por um grupo mais ou menos delimitado de atores coletivos para cumprir papéis específicos e predeterminados de intermediaçáo. Sáo "institucionalizados" na medida em que implicam a transferência de recursos e autoridade de

4 Este artigo reformula e avança argumentos escritos originalmente para um capítulo do livro organizado por Federico M. Rossi e Marisa von Bülow, Social movements in Latin America: new theoretical trends and lessons from a mobilized region. (ASHCATE, no prelo). 
outros atores e, assim, adquirem certa independência e aumentam as relaçóes organizacionais e não puramente voluntárias entre os mesmos. ${ }^{5}$ Graças a sua institucionalização, esses intermediários são responsáveis por várias funçóes de intermediação que não poderiam ser realizadas por outras organizaçóes individualmente, isto é, eles trazem consigo capacidades emergentes ou novas de ação e coordenaçáo para os atores que os criam; ao mesmo tempo, dependem do apoio material e simbólico de seus fundadores para exercer tais funçóes. Os brokers institucionalizados podem assumir diferentes formatos organizativos, que vão desde organizaçóes que coordenam coalizóes de organizaçóes não governamentais (ONGs) e federaçóes de sindicatos até associaçóes mais heterogêneas, como frentes, que cumprem funçóes de intermediaçâo entre organizaçóes da sociedade civil.

Entendemos a institucionalização como um processo dinâmico que apresenta dilemas ou, mais especificamente, trade-offs a brokers e atores intermediados. ${ }^{6}$ Como argumentam Stovel e Shaw (2012) em seu recente panorama da literatura sobre brokerage, praticamente náo há pesquisas sobre como os atos de intermediação moldam as relaçóes posteriores. As autoras também apontam corretamente o fato de os dilemas associados à intermediação raramente serem abordados em debates teóricos. Baste atentar para o fato de que, inclusive do ponto de vista dos brokers, o desempenho de funçóes de intermediação pode estar submetido à negociação contínua e intensa com aqueles que os apoiam e a quem eles têm de prestar contas.

A análise desenvolvida neste artigo procura ajudar a preencher essas lacunas. A decisáo de criar organizaçóes especializadas para cumprir funçóes de intermediaçáo no âmbito das organizaçóes da sociedade civil e entre estas e atores externos não é automática, nem é uma escolha necessariamente fácil ou isenta de custos. Na verdade, é uma decisáo delicada para os atores, porque implica escolhas entre, de um lado, concentraçáo de recursos e autoridade em mãos de terceiros, e, de outro, autonomia e pluralidade, bem como economia de recursos no caso dos atores individuais. Trata-se, em termos abstratos, de

5 Relações puramente voluntárias são aquelas que descansam apenas na persuasão moral. Para uma análise cuidadosa do componente não voluntarista da associação, ver Warren (2004).

6 Dilemas comportam proposições conflitantes ou contraditórias, ou escolhas entre opções indesejáveis ou, pelo menos, dificeis porque igualmente inconvenientes. Já os trade-offs remetem a escolhas entre opções igualmente desejáveis, cada uma associada aos seus próprios riscos elou custos. 
trade-off conhecido e associado à efetividade da ação política, a qual, mesmo que desejável, implica restriçóes à autodeterminação dos atores individuais. $\mathrm{Na}$ formulaçáo singela de Dahl (1994, p. 28), o dilema democrático entre efetiva participaçáo individual e efetividade agregada opóe um maior controle direto, desejável, mas sobre questôes de relevância menor, e a capacidade de agir em questóes de maior envergadura, em que, todavia, a capacidade de influência dos atores individuais resta consideravelmente reduzida.

Com o intuito de avançar na construçáo de teoria e no desenvolvimento de conceitos que permitam pensar a variação das formas de intermediação no seio da sociedade civil e os dilemas associados a sua institucionalização, desenvolvemos neste artigo uma tipologia de brokers institucionalizados - associaçóes pico, conglomerados associativos, entidades multissetoriais - baseada principalmente nas regras de pertencimento que definem as fronteiras de tais brokers, em algumas características organizacionais correlatas, bem como na diferenciação entre papéis de intermediação internos e externos. É pelo fato de as regras de pertencimento trazerem consigo diversas implicaçóes relevantes - inclusive para lidar com os trade-offs da institucionalizaçáo - que desempenham aqui o papel de fulcro para um conjunto maior de distinçóes analíticas. $\mathrm{Na}$ tentativa de melhor compreender o processo de institucionalizaçáo da intermediaçáo e seus dilemas, e de modo consoante com o dilema democrático de Dahl, tratamos das vantagens e das desvantagens em termos de efetividade - as quais sáo inerentes a iniciativas de intermediação na medida em que buscam viabilizar funçóes de traduçáo, coordenaçáo, articulaçáo e representaçáo em escalas abrangentes ou superiores às da açáo de atores individuais.

A institucionalização da intermediação é um fenômeno particularmente relevante em contextos de ecologias organizacionais ampliadas da sociedade civil, como as que encontramos atualmente no Brasil, no México e em outros países da América Latina. ${ }^{7}$ Servindo-nos da sociologia organizacional e de nosso próprio trabalho anterior, definimos ecologias organizacionais

7 A literatura sobre mobilização na América Latina aponta para a crescente heterogeneidade das associações da sociedade civil depois das transições para a democracia. Por exemplo. Avritzer (1992) argumenta que, paralelamente aos processos de democratização, ocorreram duas mudanças importantes nos padrões de ação coletiva na região: a ruptura com um padrão de homogeneização da ação (possibilitada por causa de uma diminuição importante na relevância das organizações sindicais) e o aumento do número e variedade de associações civis. 
ampliadas como populaçōes diversificadas de organizaçóes da sociedade civil que criam formas organizacionais especializadas para lidar com sua interdependência dentro de ambientes compartilhados (HANNAN; FREEMAN, 1989; HANNAN; PÓLOS; CARROL, 2007; GURZA LAVALLE; BUENO, 2011, 2010). A pertinência da tipologia desenvolvida para se pensar em formas organizacionais emergentes na região - como parte de ecologias organizacionais ampliadas em níveis nacionais e transnacionais - será mostrada mediante um exercício de aplicação a casos de associaçôes pico, conglomerados associativos e entidades multissetoriais no México e no Brasil. A aplicação revelará que os atores encontram formas de compensar os riscos da institucionalizaçáo tanto no terreno das relaçóes intraorganizacionais como naquele das relaçóes entre organizaçóes; também evidenciará que a institucionalização não garante a estabilidade da posição do broker.

O artigo está organizado em três partes. A primeira contextualiza historicamente a institucionalizaçáo de intermediários no mundo da sociedade civil e faz uma breve revisão da literatura sobre intermediação. A segunda apresenta a tipologia dedutiva de brokers institucionalizados - antecedida pelo exame de duas tipologias indutivas que serviram de ponto de partida - e examina as implicaçóes de seu critério analítico vertebral - regras de pertencimento - e de características correlatas relevantes. A terceira parte realiza um exercício de aplicaçáo que ajuda a explicar o papel desses tipos de organizaçóes e as perdas e ganhos enfrentados pelos atores que as criam e pelos próprios brokers. Essa parte está subdividida em duas seçôes. A primeira analisa casos de conglomerados associativos com base no estudo dos papéis exercidos por novas organizaçóes transnacionais, criadas no Brasil e no México no contexto de mobilizaçôes relacionadas a acordos de livre comércio. A segunda seção analisa casos de associaçóes pico e de entidades multissetoriais, focando a atençáo no papel que elas cumprem dentro das ecologias organizacionais da sociedade civil do pós-transiçáo na Cidade do México e em São Paulo.

Essas duas últimas seçóes reúnem resultados de dois projetos de pesquisa distintos; projetos baseados em diferentes perguntas de pesquisa, níveis de análise e classe de dados. Apesar dessas diferenças, a institucionalizaçáo da intermediação apareceu como central em ambos os casos, mantendo-se subestudada e conceitualmente subdesenvolvida em nossas publicaçóes anteriores. Concluímos apontando algumas das implicaçóes teóricas da análise de 
diferentes tipos de brokers institucionalizados e apresentando a agenda de pesquisa que temos para o futuro.

\section{Brokerage na sociedade civil: fenômeno e questão analítica}

Seria um equívoco afirmar que a institucionalização da intermediaçáo na sociedade civil constitui fenômeno novo. Organizaçôes de intermediaçáo existem há muito tempo, apresentadas na literatura sob diferentes nomes. Suas raízes remontam pelo menos ao século XIX, às federaçóes norte-americanas de mulheres estudadas por Skocpol (1992) ou às associaçóes gerais de artesãos mexicanos analisadas por Forment (2003, p. 108-109). No século XX, Morris analisa as tarefas fundamentais de tradução e coordenação desempenhadas por "centros de movimento" para o movimento dos direitos civis nos Estados Unidos. Estes "serviram como antenas receptoras e 'transmissoras' para os sit-ins ["sentadas" ou ocupaçóes]. Como receptores, esses centros reuniam informaçóes das ocupaçóes; como transmissores, retransmitiam essas informaçóes em todas as redes" (MORRIS, 1981, p. 757).

Porém, como questáo teórica, a intermediação exercida por atores institucionalizados no seio da sociedade civil é mais recente e guarda um estatuto ambíguo, identificável no caráter ambivalente da figura do broker ou do brokerage e presente na própria origem etimológica desses vocábulos. Seus significados remetem a uma conotação etimológica dupla: comércio e intermediação imoral. Broker deriva da palavra francesa "brocour" (pequeno comerciante), corrente no século XIV (HARPER, 2014), que, por sua vez, provém de termos do francês antigo usados para designar o varejista de vinho e cerveja e, por extensão, a ação de servir cerveja de barril (abrokur e brocheor). O broker era, assim, um varejista de álcool e intermediário da circulaçáo de bebidas embriagantes. Essa conotação dupla ganhou contornos mais claros no inglês, em que significava simultaneamente mascate e cafetão (HARPER, 2001, 2014). ${ }^{8}$

8 "Intermediação" e "intermediário" são opções utilizadas de modo intercambiável com os conceitos brokerage e broker. Trata-se, por um lado, de uma opção estilística, para variar o repertório de vocábulos disponiveis ao longo do texto, e não de uma tradução a ser aplicada sistematicamente ao longo do texto. Por outro lado, a opção é analiticamente pertinente. "Intermediação" e "intermediário" podem ser especificadas em categorias regionais ou temáticas específicas, conforme o âmbito em questão, por exemplo, corretor, no mercado de bens, ou "cabo eleitoral" no "mercado" de votos. A própria origem etimológia de "intermediação" encerra uma ambiguidade semelhante (GURZA LAVALLE; ZAREMBERG, 2014) em que o interesse/lucro do intermediador aparece ora como beneficio legitimo ou ilegitimo da intermediação. A expressão da fala comum "atravessador" 
De fato, a ambivalência pode ser identificada na literatura como ênfase nos benefícios auferidos pelo intermediário - ora atingidos legitimamente ou mediante abuso de sua posiçáo - ou naqueles gerados a favor dos intermediados.

Tal ambiguidade é perceptível, por exemplo, na literatura de análise de redes sociais, campo de estudos que incorporou questóes de intermediaçáo pela própria natureza do seu método e pelo progressivo desenvolvimento de conceitos e medidas preocupadas com a centralidade indireta dos atores (betweenness) - a qual, por definiçáo, supóe brokerage entre atores de uma rede como propriedade estrutural. Assim, Marsden elaborou sua influente definiçáo em 1982, segundo a qual brokerage é um processo "pelo qual atores intermediários facilitam transaçóes entre atores que náo têm acesso uns aos outros ou que náo confiam uns nos outros" (MARSDEN, 1982, p. 202). Nesse sentido, brokers desempenhariam uma função positiva, resolvendo problemas de coordenação. Contudo, dada sua posiçáo estrutural na rede, conseguiriam também explorar as vantagens da desconexão entre atores, preservando sua incomunicabilidade ou, na conhecida formulação de Burt $(1992,2005)$, esforçando-se em preservar os "buracos estruturais" da rede. A própria literatura de análise de redes questionou o fato de se derivarem funçóes políticas ou sociais de posiçóes estruturais, quer dizer, assumir que a posiçáo em uma determinada estrutura de vínculos equivale ao exercício de papéis de intermediação do ponto de vista sociológico ou politológico (GOULD, 1989; GOULD; FERNANDEZ, 1989; VASI, 2011). O debate contemporâneo sobre intermediação na literatura de movimentos sociais e sociedade civil se apoia nessas formulaçóes pioneiras, mas, como será visto mais adiante, tende a enfatizar o impacto positivo dos brokers nos processos de mobilizaçáo.

$\mathrm{Na}$ América Latina, a antropologia política e a literatura neocorporativa contribuíram a enriquecer significativamente nossa compreensão da intermediaçáo política. No primeiro caso, e focando a atençáo sobre a microdinâmica da açáo coletiva, os brokers sáo intermediários entre patróes, possuidores de recursos materiais e políticos, e clientelas que, sob regras de reciprocidade, trocam tipicamente votos ou alguma outra forma de fidelização política por

evidencia emblematicamente o aspecto negativo da intermediação, e as dificuldades associadas ao emprego do conceito "clientelismo" revelam como a linguagem acadêmica se defronta com as mesmas ambiguidades. Ver o excelente trabalho de Gay (1999). 
parcelas de benefícios (AUYERO, 1999a). Os intermediários variam conforme as especificidades culturais do contexto - capituleros, punteros, padrinos, cabos eleitorais (AUYERO, 1999b, p. 467-468), mas desempenham papéis analiticamente equivalentes e operam como figuras que resolvem problemas da clientela. Assim, os brokers sáo parte fundamental de uma rede de clientelismo, que varia conforme o funcionamento interno dos partidos políticos (LEVITSKY, 2001) e se encontra formada por outros dois atores: a autoridade política/partidária e a clientela - geralmente pobres urbanos. As organizaçóes civis e/ou os movimentos sociais, todavia, náo foram o foco privilegiado dessa literatura.

No terceiro quartel do século XX, a literatura neocorporativista outorgou status analítico claro à institucionalizaçáo da intermediação de atores da sociedade civil inscritos no mundo do trabalho e ofereceu uma resposta que náo apenas enfatizou os benefícios desejáveis da institucionalização, mas equacionou os desafios implicados pelos processos de intermediação. ${ }^{9}$ Concentrando-se em estruturas de intermediaçáo de interesses entre atores de classe e o Estado, e atentando para a importância dos mecanismos de representaçáo que vão além do domínio eleitoral, as visóes neocorporativistas sobre a intermediação argumentaram explicitamente em favor da institucionalizaçáo, devido à sua eficácia (SCHMITTER, 1974, 1971; MALLOY, 1977). Mais do que isso: institucionalizar a intermediação através da representaçáo, apesar de implicar perda de autonomia para atores individuais, foi valorizado como a melhor opçáo porque a fragmentaçáo de atores e interesses enfraquece a eficácia das reivindicaçóes (SCHMITTER, 1974, p. 97, 100, 109). Nas palavras incisivas de Schmitter (1992, p. 439): "as associaçôes pluralistas enfraquecem o papel dos intermediários de interesses; as corporativistas o fortalecem". Assim, o trade-off democrático é resolvido sem hesitaçáo privilegiando a efetividade agregada à custa do pluralismo, quer dizer, da autodeterminaçáo e controle direto dos atores individuais. Contudo, os argumentos dessa literatura náo são facilmente transferíveis a outros campos de ação da sociedade civil, nos quais a institucionalização da intermediaçáo não é concedida pelo Estado, e a gama empírica de atores incluídos é muito maior e, sobretudo, mais diversificada.

9 Existe uma vasta literatura sobre corporativismo e neocorporativismo na América Latina, cuja revisão está além dos objetivos deste capítulo. Para uma análise crítica sobre os usos destes conceitos em sua aplicação ao caso do México, ver, por exemplo, De la Garza (1994, p. 20-27). 
Mais recentemente, a literatura sobre movimentos sociais e protestos na América Latina tem reconhecido o papel fundamental cumprido por tipos emergentes de brokers institucionalizados, apontando lacunas no estado do conhecimento. Um estudo realizado, entre outubro de 2009 e setembro de 2010, pelo Programa das Nações Unidas para o Desenvolvimento (PNUD) (2011), sobre conflitos sociais em 17 países latino-americanos, destaca o papel das "coordenadoras de movimentos sociais". Estas são definidas como "organizaçóes de segunda ordem que funcionam como uma espécie de guarda-chuva institucional reunindo movimentos sociais com demandas semelhantes" e "cuja principal função é reforçar a coordenação com organizaçóes de base ou com atores individuais" (PAPEP/UNDP, 2011, p. 158). $\mathrm{O}$ estudo ainda argumenta que essas organizaçóes geram supraidentidades coletivas com base em dinâmicas relativamente novas que ainda náo foram estudadas adequadamente.

Em outras palavras, reconhece-se a institucionalização da intermediação como fenômeno emergente e sistematizam-se alguma das suas feiçóes descritivas, mas insta-se a produçáo de conhecimento no plano descritivo, sem avançar no plano teórico conceitual. Da mesma forma, em sua análise comparativa sobre "confronto antineoliberal" na América Latina, Silva (2009, p. 3-4, 41) argumenta que uma das condiçóes necessárias para os episódios de confronto que aconteceram nesses países foi a capacidade dos atores da sociedade civil de agirem como brokers, intermediando acordos que lhes permitissem formar coligaçóes entre movimentos antineoliberais. Na Argentina, por exemplo, setores do movimento dos trabalhadores conseguiram coordenar açóes que incluíam líderes comunitários e de desempregados (SILVA, 2009, p. 87).

Apesar de todos esses precedentes, a literatura oferece apenas alguns esforços para especificar conceitualmente as diferenças entre organizaçóes que atuam como intermediárias - atribuindo, em geral, valência positiva à intermediação. Durante a década de 1980, a literatura sobre movimentos sociais destacou o papel dos atores intermediários para facilitar processos de mobilização (SNOW; ZURCHER; EKLAND-OLSON, 1980; KLANDERMANS; OEGEMA, 1987; FERNANDEZ; McADAM, 1988). Na última década, a intermediação recebeu atenção mais ampla, como parte das discussóes sobre mecanismos e processos nas explicaçóes acerca da chamada de política contenciosa ou de confronto (contentious politics). Com base nas definiçóes utilizadas 
por analistas de redes sociais, McAdam, Tarrow e Tilly (2001, p. 26) definiram a intermediaçáo como "o vínculo entre dois ou mais lugares sociais (social sites) atualmente desconectados e feito por uma unidade que intermedeia as relaçóes de uns com os outros e/ou com um outro lugar (site)". No trabalho desses autores - como em grande parte da literatura de análise de redes sociais -, tal "unidade" poderia ser representada por indivíduos ou organizaçóes que exerçam papéis positivos fundamentais ao criar novas conexóes e facilitar o fluxo de recursos.

Sem dúvida, compreender a intermediação desta maneira contribuiu para esclarecer um mecanismo relacional que ajuda a explicar a difusão dos movimentos sociais; entretanto, não diferencia os tipos de brokers ou os papéis de intermediaçáo. Mais especificamente, pouco ajuda para se compreender a institucionalização da intermediação, que - diferentemente da intermediação informal especificada na abordagem da política contenciosa - tende a acontecer como decisão interna em ecologias organizacionais já ampliadas ou em processo de ampliaçáo, dentro das quais os atores podem ter laços anteriores, que buscam fortalecer ou transformar. $\mathrm{Na}$ verdade, vincular "lugares sociais atualmente desconectados" é um papel que provavelmente será cumprido por muito poucos atores com características diferenciadas, os quais podem eventualmente estar cientes de sua própria singularidade e agir para manter essa vantagem - tal e como mostrou uma parte da literatura de análise de redes (BURT, 1992). Mais recentemente, Mische (2008) propôs uma visão mais ampla sobre as posiçóes dos brokers dentro das redes de atores e mobilizaçáo sociais, argumentando que a "existência de aglomerados completamente desconectados é apenas um caso-limite em relaçáo a formas parciais de intersecção e disjunção, de ocorrência mais comum" (48, ver também VON BÜLOW, 2011). Além disso, conforme será assumido na próxima seçáo, os impactos da intermediaçáo náo podem ser definidos de antemáo. Eles náo são inerentemente bons ou maus, seja para espalhar a mobilizaçáo social ou para promover os interesses dos atores objeto da intermediaçáo.

\section{Variedades de brokers e desafios da institucionalização}

Partimos de esforços analíticos recentes, voltados para América Latina e preocupados com associar atores empíricos a tipos de intermediaçáo generalizáveis. Com maior precisão, duas tipologias de organizaçóes de intermediação 
forneceram a base para a tipologia aqui proposta - ambas, por sinal, publicadas na última década e construídas indutivamente com base em instrumentos de pesquisa muito semelhantes. ${ }^{10}$ A primeira faz parte de um projeto de pesquisa comparativo e amplo, coordenado por Ruth Collier e cujos resultados vieram à luz em volume organizado por Collier e Handlin (2009). No contexto do que consideram uma mudança histórica na forma de organizaçáo dos interesses populares na América Latina, os autores se propóem a examinar como essa mudança afeta as possibilidades de escalar demandas por parte de atores vinculados a esses interesses. De acordo com sua análise, e com base nos resultados de surveys de associaçóes realizados em Buenos Aires (Argentina), Santiago (Chile), Lima (Peru) e Caracas (Venezuela), houve uma transiçáo no regime de interesses na regiáo, passando-se do que os autores chamam de regimes centrados em núcleos sindical-partidários (union-party hub, ou $U P-H u b$ ) para configuraçóes emergentes estribadas em redes associativas (associational networks, ou $A-N e t$ ). Fundamental nessa transiçáo é que as redes de associaçóes comunitárias e organizaçóes não governamentais (atores "A-Net") substituíram os sindicatos filiados a partidos (atores "Up-Hub”) como organizaçóes predominantes para a mobilização popular e para a intermediação de interesses populares perante o Estado. ${ }^{11}$

No capítulo que analisa as novas modalidades de escalar demandas populares, Handlin e Kapiszewski (2009, p. 230) definem-nas como formas de "coordenação realizada entre entidades organizacionais". Eles identificam dois tipos de "associaçóes coordenadoras", ou seja, "aquelas para as quais coordenar outras associaçóes é uma função central” (HANDLIN; KAPISZEWSKI, 2009, p. 231): ONGs nodais e frentes flexíveis. Conforme os resultados do survey, para associaçóes de ambos os tipos coordenarem outras associaçóes é uma atividade importante e trabalham com, pelo menos, cinco outras associaçóes. No entanto, elas raramente recebem poder formal para representar outras organizaçóes, o que, argumentam os autores, significa que as

10 As perguntas base para o survey de associações que deram origem às duas tipologias aqui examinadas foram escritas conjuntamente entre os membros dos projetos de pesquisa. O questionário foi desenhado em $200 \mathrm{I}$, testado em 2002 e aplicado em anos sucessivos nos diferentes paises contemplados pelas duas pesquisas.

II As implicações mais gerais desse diagnóstico para América Latina foram revisadas recentemente no seminário "A New Critical Juncture? Changing Patterns of Interest Representation and Regime Politics in Contemporary Latin America”, sediado no Kellogg Institute for International Studies, 24-26 de abril de 2014. 
coordenadoras da A-Net estão em um plano horizontal em relação a outras cujas atividades elas dirigem e coordenam dentro da rede - uma diferença importante em relação às típicas coordenadoras no mundo do trabalho do UP-Hub (HANDLIN; KAPISZEWSKI, 2009, p. 231-232).

As diferenças entre estes dois tipos estáo relacionadas aos seus recursos organizacionais e financeiros, ao seu nível de democracia interna e a ligaçóes com atores externos à A-Net (231-245). As ONGs nodais se identificam como ONGs, têm mais probabilidades de ter laços financeiros e organizacionais com organizaçóes e governos nacionais, estaduais e internacionais, e suas práticas de governança interna são caracterizadas como participaçáo sem democracia. As frentes flexíveis, ao contrário, identificam-se como redes, federaçóes ou como mesas de concertaçáo. Elas estáo entre as entidades associativas menos institucionalizadas, tendem a nảo ter laços com atores externos com potencial para comprometer sua autonomia e sáo altamente participativas e democráticas. Por exemplo, os dados da pesquisa mostram que elas têm muito mais chances de assumir práticas democráticas em termos de eleiçóes internas do que todas as outras associaçóes (241).

A segunda tipologia a que recorremos foi proposta por Gurza Lavalle e Bueno (2011), com base em uma pesquisa similar com associaçóes realizada em São Paulo (Brasil) e na Cidade do México (México). Os autores argumentam que a ampliação das ecologias organizacionais nessas cidades implicou um processo de diferenciação e de especialização funcional na sociedade civil. Como também afirmamos neste artigo, essa ampliaçáo náo levou a um deslocamento da importância de velhas organizaçóes da sociedade civil para outras novas, e sim a uma ecologia organizacional mais complexa na qual não apenas coexistem diferentes tipos de organizaçóes, mas associaçóes especificamente institucionalizadas para realizar funçōes de intermediaçáo cumprem um papel fundamental.

Os autores propóem diferenciar organizaçóes de primeiro, segundo e terceiro níveis (GURZA LAVALLE; CASTELLO; BICHIR, 2007). Naquelas de primeiro nível, organizadores e beneficiários pertencem aos mesmos grupos sociais e normalmente se definem como parte da mesma categoria social ou da mesma comunidade, por vezes, territorialmente delimitadas - centros comunitários de jovens, associaçóes de idosos, associaçóes de moradores e 
grupos religiosos de autoajuda. As organizaçóes de segundo nível, por sua vez, geralmente trabalham para terceiros, ou seja, organizadores e beneficiários normalmente pertencem a diferentes grupos sociais e os segundos não identificam os primeiros como membros do mesmo grupo social ou da mesma comunidade da qual eles fazem parte. Por sua vez, os organizadores (por exemplo, membros de ONGs de defesa de causas, ONGs de fomento local, ou associaçóes de assistência social) costumam descrever seus beneficiários como públicos, populaçóes-alvo ou setores da populaçáo afetados por tipos específicos de vulnerabilidade social, econômica e política (GURZA LAVALLE; CASTELLO; BICHIR, 2008, p. 468-472). Organizaçôes do terceiro nível, por outro lado, náo trabalham para pessoas, e sim para outros atores sociais, ou seja, são organizaçóes fundadas por outras organizaçôes civis com o objetivo de cumprir funçóes de coordenaçáo. Portanto, devem executar tarefas institucionalizadas de intermediação.

Gurza Lavalle e colegas também propóem uma tipologia das organizaçôes de terceiro nível, desenvolvida indutivamente a partir dos resultados do survey de associaçóes e considerando a relação com os beneficiários e os repertórios distintivos de atividades por elas exercidos. Trata-se de dois tipos de associaçóes: articuladoras e fóruns. As articuladoras estão entre os atores mais centrais dentro das redes da sociedade civil na Cidade do México e em Sáo Paulo, e se encontram acopladas em termos relacionais a ONGs, mas náo são, elas próprias, ONGs - visto que as últimas sáo tipicamente associaçóes de segundo nível (GURZA LAVALLE; BUENO, 2011). Além de articular agendas, estratégias e açóes coletivas comuns entre seus membros, as articuladoras agregam e escalam reivindicaçóes, e representam seus membros diante de autoridades públicas e outros atores da sociedade civil. Os fóruns, por sua vez, são menos centrais e funcionam principalmente como espaços da sociedade civil para o adensamento de consensos em torno de políticas específicas e para a promoçáo de agendas básicas comuns entre seus membros.

As duas tipologias contribuem para a compreensáo da variedade de brokers presentes no seio da sociedade civil, mas apresentam certas limitaçóes para os propósitos deste artigo. No plano mais geral, essas tipologias seguem uma lógica indutiva, enquanto aqui, devido ao foco no desenvolvimento conceitual, parte-se de um critério geral - regras de pertencimento que definem as 
fronteiras dos atores intermediados pelos brokers - e derivam-se analiticamente implicaçóes desse critério náo penas para a classificaçáo empírica de atores, mas, sobretudo, para outras dimensóes crucias da ação coletiva. Além disso, as tipologias examinadas acima sáo empiricamente mais amplas do que a nossa, pois classificam o conjunto de atores encontrados nas pesquisas nas diferentes cidades, e náo apenas aqueles dedicados a atividades de intermediaçáo entre organizaçóes da sociedade civil. Por fim, devido à diversidade empírica encontrada, ambas as tipologias utilizaram critérios de classificaçáo apenas parcialmente relacionados ao exercício de papéis de intermediação. Como estamos interessados em papéis de intermediação institucionalizados e os trade-offs inerentes à institucionalizaçáo, introduzimos distinções mais claras.

Como mostrado na Quadro 1, diferenciamos três tipos de brokers institucionalizados: associaçóes pico, conglomerados associativos e entidades multissetoriais. Em primeiro lugar, cada tipo é definido em funçáo de quem faz ou nâo parte da organização, ou seja, das regras de pertencimento que demarcam as fronteiras entre um ator coletivo composto e fundado por outros atores coletivos e os atores externos ao seu ambiente. As regras de pertencimento constituem, nesse sentido, aquilo que Diani (no prelo) chamou de "mecanismo de definiçáo de limites". De acordo com esse critério, a variedade de brokers institucionalizados é passível de diferenciação em termos do grau de formalizaçâa e, consequentemente, rigidez de suas regras de pertencimento ou fronteiras. Em um extremo, graus elevados de institucionalizaçáo supóem a criação de organizaçóes lançando mão de expedientes jurídicos que criam obrigaçóes estatutárias; no outro, fronteiras rígidas se desmancham e cedem passo a critérios implícitos relativamente flexíveis. A consequência mais óbvia das regras de pertencimento é que a variaçáo no seu grau de formalização - das mais formais às menos formais - traz consigo, por definiçáo, efeitos inversos quanto à pluralidade de participantes na organizaçáo intermediadora - dos menos plurais aos mais abertos à participaçáo de atores diversos.

Esse critério basilar - regras de pertencimento - tende a covariar com características importantes das relaçóes entre o broker institucionalizado e seus membros, e da definiçáo de objetivos que, em princípio, ele tem ao seu alcance. Com efeito, diferentes regras de pertencimento estão intimamente vinculadas a diferentes modalidades de relaçáo entre o intermediário 
institucionalizado e seus membros. Laços formais, amiúde legalmente estatuídos no caso das associaçóes pico, comportam relaçóes baseadas em filiação, ordenadas por direitos e obrigaçóes do broker e dos membros. Por sua vez, laços mais vagos e informais, próprios da participação de associaçóes em entidades multissetoriais, ordenam as relaçóes entre o broker e seus membros de forma igualmente laxa, mediante a orientaçáo de condutas por adesão voluntária a consensos mínimos produzidos entre atores que se encontram como participantes de determinados espaços ou instâncias.

O grau de formalização das regras de pertencimento e, por conseguinte, a pluralidade dos atores intermediados pelo broker e as modalidades de relaçáo entre broker e membros também constrangem o alcance dos objetivos a serem definidos. O escopo dos objetivos que os brokers podem plausivelmente se propor a atingir é constrangido náo apenas pelos recursos a ele concedidos, mas também pelo fato de os atores intermediados se disporem a manter seus laços com o broker apenas em torno de certos objetivos. Mais uma vez, essa segunda dimensáo correlata tende a covariar com o critério basilar, embora náo implique necessariamente uma sequência que vai de objetivos mais específicos aos mais amplos ou mais vagos. A variação, neste caso, está relacionada ao denominador comum que une os participantes destas iniciativas de intermediaçáo organizacional, o qual é mais restrito quanto menos formalizada a intermediação e vice-versa. 


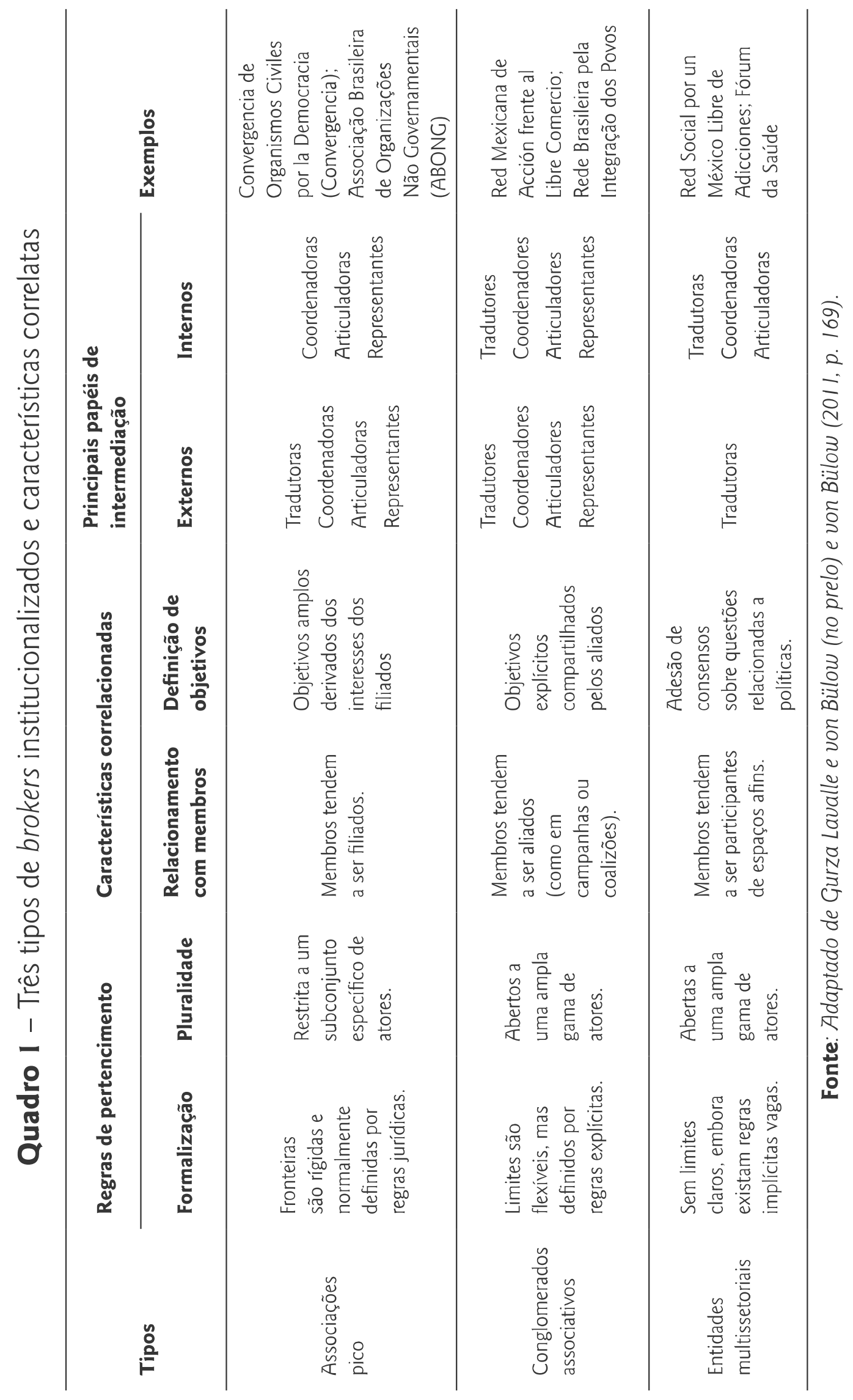


Por fim, é oportuno entender a diversidade de papéis que os brokers podem exercer, bem como as tarefas específicas a eles correspondentes. Para tanto, é útil pensar em termos de uma "escada da intermediaçáo"12 que vai das tarefas mais simples às mais complexas. A Quadro 2 permite sintetizar um volume considerável de informação acerca das relaçóes entre papéis e tarefas principais, enquanto a Quadro 1 associa tais papéis e os tipos de brokers. As tarefas mais básicas próprias à intermediação são aquelas relacionadas com o papel de "tradutor". São semelhantes à descrição de Morris (1981) sobre os "centros de movimento" durante as mobilizaçóes pelos direitos civis nos Estados Unidos, que recebiam informaçóes e as retransmitiam. Ao falar em termos de "traduçáo", no entanto, ressaltamos que os brokers muitas vezes reformulam ou, com maior precisáo, recodificam e decodificam as informaçóes recebidas ou emitidas. À medida que os atores ascendem na escada, assumindo papéis de coordenação, articulação e representaçáo, as tarefas correspondentes exigem processos mais complexos de negociaçáo internos e externos.

Nem os papéis nem suas tarefas correspondentes são excludentes entre si, mas são mais ou menos importantes dependendo do tipo de broker, e também podem ser combinados de maneiras diferentes. Assim, enquanto uma maior pluralidade torna mais relevante o papel de tradutor (Quadro 1), menos formalizaçáo pode impor limitaçóes à realizaçáo de tarefas de representação e, em termos mais gerais, às tarefas de intermediaçáo externa. Se os brokers executam ou náo todas essas funçóes é uma questão empírica, como será discutido a seguir, mas, no mínimo, elas supóem articulação de iniciativas conjuntas e negociação de marcos (frames) comuns quando exercida a intermediaçáo interna, e a definiçáo de uma agência unificada para a vocalizaçáo das reivindicaçóes dos membros quando os brokers se dedicam à intermediação externa.

12 Com base em nosso trabalho anterior, nos apoiamos na proposta de Sherry Arnstein (1969) de "escada da participação". Ver von Bülow (2011, p. 168). 


\section{Quadro 2 - A escada da intermediação}

\begin{tabular}{|c|c|c|}
\hline $\begin{array}{l}\text { Tipo de papel } \\
\text { exercido }\end{array}$ & Principais tarefas internas & Principais tarefas externas \\
\hline Tradutor & $\begin{array}{l}\text { Recepção, decodificação e difusão da } \\
\text { informação. }\end{array}$ & $\begin{array}{l}\text { Transmissão, codificação e difusão } \\
\text { da informação. }\end{array}$ \\
\hline Coordenador & $\begin{array}{l}\text { Divisão de trabalho entre os } \\
\text { participantes. } \\
\text { Recepção e distribuição de recursos. } \\
\text { Busca de contato com novos } \\
\text { participantes potenciais. }\end{array}$ & $\begin{array}{l}\text { Definição de compromissos comuns. } \\
\text { Procura e negociação de recursos. } \\
\text { Busca de contato com atores } \\
\text { relevantes. }\end{array}$ \\
\hline Articulador & $\begin{array}{l}\text { Promoção de diálogo para construir } \\
\text { consenso. } \\
\text { Capacitação. } \\
\text { Monitoramento de negociações e/ou } \\
\text { debates. }\end{array}$ & $\begin{array}{l}\text { Promoção do diálogo para } \\
\text { promover plataformas discursivas } \\
\text { compartilhadas. } \\
\text { Acompanhamento dos rumos de } \\
\text { leis, eventos e debates. }\end{array}$ \\
\hline Representante & $\begin{array}{l}\text { Consulta sobre decisões específicas. } \\
\text { Informações sobre desdobramentos } \\
\text { relacionados a tarefas de representação. } \\
\text { Harmonização de agendas internas e } \\
\text { externas. }\end{array}$ & $\begin{array}{l}\text { Falar em nome dos membros em } \\
\text { comitês, conselhos, audiências } \\
\text { públicas, elou mesas de negociação. } \\
\text { Expressão de reivindicações e } \\
\text { posições na esfera pública. }\end{array}$ \\
\hline
\end{tabular}

Fonte: Adaptado de von Bülow (201 I, p. 169).

As associaçóes pico têm limites mais rígidos na definição de membros e perfis menos plurais quanto à participaçáo do que os outros dois tipos. Sua composiçáo costuma ser restrita a um subconjunto específico de atores com determinadas características afins que, normalmente, estão relacionados à associação por filiaçáo, como no caso das centrais sindicais, que reúnem grupos de sindicatos, e das associaçóes de ONGs, que restringem o acesso a um tipo predefinido de organização - seja por afinidades político-ideológicas ou funcionais. As associaçóes pico são criadas para cumprir papéis externos de intermediaçáo, principalmente os de representaçáo, que também supóem o desempenho de funçóes internas de articulação, coordenação e representação. Devido à homogeneidade interna, elas não precisam desempenhar o papel de tradutoras entre seus membros, embora efetuem tarefas de codificaçáo e decodificação em face dos atores externos. A filiação geralmente é um vínculo com status jurídico, e as associaçóes pico não raro contam com estatutos que 
indicam um conjunto básico de compromissos institucionais a serem cumpridos no interesse dos filiados. Graças à formalização, esse conjunto básico de compromissos, na verdade, traduz-se em uma ampla gama de programas e projetos, na forma de atividades e metas específicas, sem que a amplidão dessa gama acarrete riscos quanto à eventual saída de membros, desde que preservado o mandato institucional de agir em determinada área no melhor interesse dos membros. Exemplos bem conhecidos nos contextos mexicano e brasileiro, criados no início dos anos 1990, são, respectivamente, Convergencia no México e a ABONG no Brasil.

Nos casos dos conglomerados associativos e das entidades multissetoriais, os limites que definem suas fronteiras são menos rígidos, ou seja, essas organizaçóes estão abertas a uma ampla gama de atores. As entidades multissetoriais reúnem organizaçóes e indivíduos que podem ser chamados de "membros" ou, por vezes, apenas de participantes, trabalhando em torno dos mesmos temas ou setores de políticas públicas. No caso dessas entidades, a participação nâo é definida com base em um status jurídico ou organizacional, mas apenas em funçáo de afinidades temáticas entre os atores que tendem a se reunir como participantes em espaços de diálogo ou em eventos específicos. Externamente, esses intermediários desempenham apenas o papel de tradutores, sem o poder de agir pelos seus membros, mas apenas de comunicar os consensos básicos alcançados. Internamente, ao funcionarem como espaços de diálogo entre atores reunidos por afinidades temáticas, tais entidades realizam funçóes de coordenaçáo, articulaçáo e tradução entre participantes. Os limites vagos e a pluralidade de atores náo permitem a definiçáa de objetivos claros que subordinem a ação dos participantes, mas apenas a definição de prioridades gerais a serem promovidas por livre adesão pelos participantes. Exemplos desse tipo de broker institucionalizado são a Red Social por un México Libre de Adicciones e o Fórum da Saúde do Brasil.

Por fim, os conglomerados associativos estáo em uma posição intermediária entre as associaçóes pico e as entidades multissetoriais em termos da definiçâao de regras de pertencimento, sendo mais flexíveis do que as primeiras e mais rígidos do que as segundas. Em contraste com as entidades multissetoriais, implicam laços mais fortes entre os atores por eles intermediados, que náo apenas sustentam afinidades temáticas, mas também abraçam pontos de vista ou entendimentos políticos comuns ao ponto de levá-los a se tornar 
aliados em campanhas e na formação de coalizóes. A declaração pública desses entendimentos ou visóes políticas e dos objetivos almejados funciona como um filtro ou uma definiçáo explícita de regras para se tornar membro da coalizáo ou da campanha. A formalizaçáo e pluralidade implicam a ausência de mandato institucional amplo. A definiçáo de objetivos claros e delimitados é, assim, condição para a sobrevivência da intermediação. Por fim, os conglomerados associativos sáo criados para desempenhar papéis internos e externos, sendo, na verdade, o tipo de broker que exerce a maior gama de papéis. Bons exemplos são as seçóes nacionais da Aliança Social Continental no México e no Brasil, analisadas na seçáo seguinte.

É importante observar que as divisóes entre estes três tipos de brokers institucionalizados sáo menos engessadas do que pode parecer quando se examina a Tabela 1 . Além disso, não são excludentes. É possível - e, na verdade, bastante comum - que a mesma organizaçáo civil participe ou seja membro de mais de um dos arranjos organizacionais definidos. Por fim, não argumentamos que um tipo de broker institucionalizado seja, a priori, mais ou menos eficiente do que os outros, nem pressupomos que um seja mais democrático do que os outros - seja qual for a definiçáo de "eficiente" e "democrático" adotada -, mas apenas apontamos o fato de existirem diferentes níveis de formalizaçáo das regras de pertencimento inter-relacionados com o alcance dos objetivos organizacionais e outras características correlatas relevantes. Assim sendo, nem a "formalização" nem a "pluralidade" são abordadas de um ponto de vista normativo. Conforme será elucidado a seguir, diferentes tipos de intermediação institucionalizada trazem consigo diferentes papéis de intermediação, e, portanto, diferentes desafios.

A criaçáo de brokers organizacionais institucionalizados é uma decisáo política que traz consigo trade-offs. Isso, a despeito de a literatura neocorporativa e as recentes contribuiçóes da literatura dos movimentos sociais terem atentado predominantemente para os impactos positivos dos brokers sobre a mobilização e a reivindicação. Como ressaltaram Hannan e Freeman (1989, p. 5) em seu trabalho seminal sobre ecologias organizacionais, "grandes quantidades de recursos organizacionais sáo usados para a construçáo de organizaçóes e para despesas gerais administrativas, e não para a produção da ação coletiva, o que faz com que a criação de uma organizaçáo permanente seja uma forma onerosa de se alcançarem objetivos sociais". Além de sua natureza onerosa, uma vez 
criadas, as organizaçōes desenvolvem sua própria lógica e os profissionais nelas empregados desenvolvem interesses próprios, gerando desafios de prestaçáo de contas perante seus fundadores - uma liçáo bem aprendida, por sinal, pelo menos desde a obra de Robert Michels, de 1911, sobre os partidos políticos e a lei de ferro da oligarquia.

Entender por que os atores da sociedade civil decidem unir forças - ou náo - vai além dos objetivos deste artigo. Nosso foco está no mapeamento conceitual de diferentes iniciativas institucionalizadas de intermediaçáo (tipologia) e dos trade-offs ou desafios que impóem aos atores que decidem participar delas. Trata-se, nos termos do conhecido dilema democrático de Dahl (1994), da difícil escolha entre efetiva participação individual e autodeterminaçáo, embora em escopos de açáo assaz limitados, ou efetividade agregada sobre âmbitos de ação relevantes, mas com peso insignificante dos atores individuais. Em outras palavras, no plano da intermediaçáo interna, organizaçóes civis têm que escolher entre concentração de poder no intermediário ou uma abordagem mais distributiva, que promove relaçóes igualitárias, mas também fragmentação de recursos e ineficiência. Sem brokers institucionalizados, a capacidade de cumprir papéis de coordenaçáo, articulaçáo e representaçáo dependerá de persuasão moral, com custos de oportunidade potencialmente elevados e o risco de perpetuar conflitos internos pela ausência de recursos organizacionais para processá-los. ${ }^{13}$ Externamente, o trade-off da efetividade impóe uma escolha entre permanecer autônomo, mas com pequenas chances de ser ouvido, ou ser ouvido e aumentar significativamente as chances de ter impacto ao agir por meio de um broker que, todavia, irá interpretar as necessidades dos atores, reduzir a pluralidade e, até mesmo, subordinar-lhes a vontade a decisóes vinculantes ou de cumprimento obrigatório.

No entanto, náo seria prudente pressupor que um conjunto de atores pertencentes a uma ecologia organizacional ampliada escolherá necessariamente o caminho da institucionalização. A institucionalização não é uma receita para o sucesso, e é possível que haja fracassos. Além disso, mesmo quando esse caminho for escolhido, o status de broker náo é imutável, e os membros podem

13 Warren (2004) apontou corretamente as dificuldades enfrentadas por associações que dependem inteiramente de relações voluntárias, sem componentes organizacionais, para lidar com o conflito interno. Nesse caso, o único meio disponivel é a persuasão moral, mas ela não resiste a muito estresse. 
desinstitucionalizar a intermediação através de estratégias de vocalização de desavenças ou de saída (voice or exit) (HIRSCHMAN, 1970). Em se tratando de uma organizaçáo que trabalha para outras organizaçóes-membros, não apenas é comum existir uma variaçáo de recursos de poder considerável entre os membros, mas alguns dos últimos podem possuir mais recursos do que próprio broker (AHRNE; BRUNSSON, 2008). Nesse sentido, a intermediação também é um empreendimento arriscado do ponto de vista do broker. A ameaça da desinstitucionalização pode se concretizar não só por causa de mau desempenho, mas inclusive porque o próprio desequilíbrio de recursos acarretado pelos papéis de intermediaçáo - especialmente em relaçáo aos membros mais desprovidos - gera suspeita permanentemente (STOVEL; SHAW, 2012). Como será mostrado na análise empírica apresentada na próxima seçáo, isso faz da institucionalizaçáo da intermediaçáo um empreendimento arriscado. Os riscos, todavia, variam conforme o tipo de broker.

\section{Os papéis dos brokers em ecologias organizacionais ampliadas}

Nesta parte do artigo, apresentamos exemplos específicos dos três tipos de brokers institucionalizados. Os exemplos iluminam a dinâmica da institucionalizaçáo da intermediaçáo e os desafios enfrentados pelos atores da sociedade civil que participam dessas iniciativas e pelos próprios brokers. Os exemplos também mostram possibilidades para atenuar os riscos da institucionalizaçáo, ora no plano das relaçóes internas à organização, ora no plano da composição das ecologias organizacionais.

Inicialmente, trataremos da análise dos conglomerados associativos, a partir dos casos da Red Mexicana de Acción frente al Libre Comercio (RMALC) e da Rede Brasileira pela Integraçáo dos Povos (REBRIP). Elas são organizaçóes transnacionais fruto dos recentes esforços de criaçáo de organizaçóes que possam cumprir funçóes de intermediaçâo dentro e fora das fronteiras nacionais. Na segunda parte desta seçáo, abordaremos os casos das associaçóes pico e das entidades multissetoriais, analisando seu papel no âmbito das ecologias organizacionais da sociedade civil de São Paulo e da Cidade do México. Conforme esclarecido na introduçâo, estas seções são baseadas em distintos projetos de pesquisa e metodologias que, apesar das diferenças, mostram o papel cada vez mais relevante dos brokers institucionalizados. Enquanto a seçáo 
sobre conglomerados transnacionais trata mais da agência dos brokers, a seção sobre associações pico e entidades multissetoriais destaca os impactos de suas posiçóes em redes de organizaçóes da sociedade civil.

\section{Conglomerados associativos e ação coletiva transnacional}

Nas últimas duas décadas, desde a negociação do Acordo de Livre Comércio da América do Norte (NAFTA, em inglês) até a negociação (fracassada) da Área de Livre Comércio das Américas (ALCA) e o lançamento da Uniāo Sul-Americana de Naçóes (UNASUL), um grupo muito amplo e heterogêneo de organizaçóes da sociedade civil das Américas foi se conscientizando da relevância dessas negociaçóes e seus impactos sobre vários públicos e arenas de políticas públicas. Para esses atores, a criação de brokers institucionalizados se tornou uma tarefa fundamental. Como resultado da crescente demanda por espaços comuns de encontro e por coordenação, eles construíram uma nova infraestrutura organizacional, hemisférica, de escala múltipla e diferentes setores. Alianças nacionais reuniram ONGs, organizaçóes de movimentos sociais, associaçóes de pequenas empresas e iniciativas religiosas, as quais, por sua vez, reuniram-se em escala transnacional, sob o guarda-chuva de uma nova coalizão, a Aliança Social Continental (ASC), que foi criada em $1997 .{ }^{14}$

Porém, nem todos os atores da sociedade civil interessados em negociaçóes comerciais participaram desses esforços. Ao decidir se e como participar da ação coletiva em escala múltipla, os atores tiveram que tomar decisóes importantes em duas etapas sucessivas. Em primeiro lugar, poderiam decidir participar desse processo de construçáo de alianças ou atuar por conta própria. Enquanto a primeira opçáo implicava a negociação dos marcos da ação com outros atores (e pelo menos alguma perda de visibilidade de organizaçóes e reivindicações específicas), a outra trazia o risco de isolamento e, portanto, de irrelevância. Em segundo lugar, ao aceitar a necessidade de fazer parte desse novo conglomerado colaborativo, os atores tiveram que decidir sobre a governança interna tanto das alianças nacionais como da ASC. Mais uma vez, isso implicou uma opçáo entre a criação de poderosas organizaçóes, de um lado, e a autonomia de seus membros individuais, de outro. Considerando-se os

14 Para uma explicação da metodologia de pesquisa adotada e uma análise mais detalhada do processo de criação da Aliança Social Hemisférica e suas seções nacionais, ver von Bülow, (20/1, 20/4). 
objetivos teóricos deste artigo, é mais interessante destacar os arranjos organizacionais relacionados a tarefas de intermediaçáo aos quais os atores chegaram.

A estrutura organizacional resultante não foi uma campanha de curto prazo nem uma estrutura hierárquica, e sim uma divisáo do trabalho flexível e de múltipla escala, entre atores que tinham em comum uma postura crítica em relação aos acordos multilaterais de comércio e um interesse em influenciar os processos de integraçáo regional da América Latina. Na tentativa de evitar hierarquias rígidas, essa estrutura se baseou em coalizóes nacionais que cumpriam os quatro papéis de intermediaçáo especificados na Quadro 2: de tradutoras, que produzem, recebem e disseminam informaçôes através das fronteiras e das línguas; de coordenadoras, necessárias para organizar a distribuição de recursos, responsabilidades e informaçấo; de articuladoras, que estabelecem pontes para reunir atores e negociar posiçóes comuns, e de representantes de um grupo mais amplo em eventos e reunióes nacionais e internacionais. Enquanto os três primeiros implicam tarefas de intermediação executadas internamente, $o$ último implica vínculos com outros atores, como autoridades do Estado. Essas organizaçóes operam como nós transnacionais, porque elas existem como parte de uma rede mais ampla organizada em nível transnacional, neste caso, sob a bandeira da ASC.

Neste artigo, trataremos das experiências de duas das 17 coalizóes nacionais relacionadas aos acordos comerciais que existiam em 2013: a RMALC e a REBRIP. ${ }^{15}$ Por meio da análise desses casos, identificaremos dilemas de intermediação semelhantes, enfrentados de modo distinto por atores inseridos em diferentes contextos políticos e sociais.

\section{I Os casos da RMALC no México e da REBRIP no Brasil}

A RMALC foi criada por um conjunto amplo de organizaçóes mexicanas da sociedade civil, em 1991, para influenciar os debates sobre as negociaçóes do NAFTA. Nos primeiros anos, foi administrada por voluntários e ocupou temporariamente um espaço na sede de uma pequena central sindical chamada Frente Auténtico del Trabajo (FAT). Em 2005, a coligaçáo tinha seis funcionários remunerados e ocupava permanentemente uma parte maior do

15 Para uma análise mais completa das mobilizações em torno dos acordos regionais de liure comércio, ver von Bülow (201I, 20 /4). 
edifício da FAT na Cidade do México. Tendo começado com 42 organizaçóes filiadas, o número cresceu para mais de 100 durante os debates do NAFTA, mas depois diminuiu. Em 2013, reunia cerca de 16 organizaçóes da sociedade civil. ${ }^{16}$

A REBRIP foi criada alguns anos depois da RMALC, no contexto das negociaçóes hemisféricas da ALCA. Em vez de passar por um processo de crescente profissionalizaçáo, semelhante ao da RMALC, a Secretaria da coalizáo manteve sua sede em uma organizaçáo já existente (na sede da Federaçáo de Órgãos para Assistência Social e Educacional - FASE, entre sua fundaçáo e 2010; e a partir de entáo, na Central Única dos Trabalhadores - CUT), com uma estrutura muito pequena e com menos dependência do que a RMALC de pessoal remunerado e da captaçâo de recursos externos. Em 2013, reunia 67 organizaçōes de movimentos sociais, ONGs e coalizóes de organizaçôes da sociedade civil. ${ }^{17}$

Apesar destas diferenças e das variaçóes no contexto político do México e do Brasil, afirmamos que os membros das duas coligaçóes enfrentaram um desafio semelhante: o de construir organizaçôes de intermediaçáo eficientes que pudessem exercer papéis de coordenação, articulação, traduçáo e representação. Esse desafio implicava, todavia, uma escolha: uma maior eficiência poderia acarretar perda de autonomia dos membros individuais. No caso das organizaçóes mexicanas que ainda pertenciam à RMALC na década de 2000, tinham passado a utilizar a coalizáo náo como coordenadora, articuladora ou representante, mas fundamentalmente como tradutora, ou um lugar de debate, produçáo e difusáo de conhecimento. A RMALC conseguiu sobreviver como a referência nacional mais importante para os atores em busca de uma análise crítica dos acordos comerciais e seus impactos, capaz de apresentar as questóes em termos que seus membros pudessem entender facilmente, ligando as negociaçóes internacionais às realidades locais. ${ }^{18}$ No entanto, não

16 Para uma lista de membros, consulte <http://www.rmalc.org.mx/integrantes.htm>, acessada em 15 de abril de 2013.

17 Para uma lista de membros, consulte <http://www.REBRIP.org.br/conteudo/34/membros>, acessada em $15 \mathrm{de}$ abril de 2013.

18 Vários dos entrevistados mexicanos destacaram o importante papel intelectual da RMALC na produção de conhecimento. Entre 199I e 2003, a RMALC publicou ou coeditou 23 publicações, além de inúmeros materiais de educação popular e boletins (MASSICOTTE, 2004, p. 289). 
conseguiu desempenhar as outras funçóes de intermediação para as quais a coalizão tinha sido criada.

Uma maneira de compreender essa atuação limitada é analisar a capacidade da RMALC de intermediar as relaçóes com atores dos outros países. Como explicou um dos membros, a dependência em relaçáo à coalizáo como porta de entrada única para chegar a aliados de outros países foi reduzida:

No início, talvez a porta fosse a RMALC, mas agora temos uma série de relações que foram construídas [...] O processo transbordou para outras questões, as pessoas se especializaram, foram estabelecidos contatos bilaterais. Agora, existem outros níveis de relacionamento.19

A dificuldade crescente da RMALC para cumprir os papéis mais complexos de intermediaçáo está relacionada não só aos riscos inerentes ao caminho de institucionalização e seu processo natural de centralizaçáo de laços e especializaçáo, mas ao que Stovel e Shaw (2012) chamaram de "dilema inevitável", raramente abordado em debates teóricos: a capacidade dos brokers de manter a confiança necessária para continuar a realizar tarefas de intermediaçáo. Como explicaram em entrevistas muitos dos ex-participantes da RMALC, a concentração do poder de decisáo em alguns indivíduos que diziam falar em nome de todos foi uma das maiores fontes de crise deste broker (VON BÜLOW, 2011, 2014). Entre a década de 1990 e a de 2000, a RMALC passou de um conglomerado associativo a algo mais próximo a uma entidade multissetorial em termos dos papéis de intermediaçáo que era capaz de desempenhar (ver Quadro 2).

No caso da REBRIP, a relaçáo entre os papéis da coalizão e a autonomia dos membros individuais foi tema de debate explícito e polêmico. Como explicou um relatório interno produzido pela REBRIP em 2007, o resultado do debate foi um desenho organizacional inovador que tentava encontrar um equilíbrio entre eficiência e autonomia:

Hoje, na Rede Brasileira pela Integração dos Povos (REBRIP), chegamos a uma dinâmica que nos permite afirmar que somos, ao mesmo tempo, um espaço e uma rede. Não somos [como] o processo do Fórum Social Mundial, uma vez que adotamos posições claras que norteiam nossas ações. No entanto, também não somos uma estrutura rígida que limite a autonomia de seus membros. Agimos com posições claras, mas com a limitação do mínimo denominador comum possível. (REBRIP, 2007).

19 Entrevista com Brisa Maya, CENCOS, Cidade do México, agosto de 2005. 
Embora tenha sido mais bem sucedida do que sua equivalente mexicana na manutençáo de uma participaçáo ampla - a despeito e graças a seu perfil mais baixo -, a REBRIP náo ficou imune ao dilema da desconfiança mencionado anteriormente. Como reconheceu a Coordenação da REBRIP, muitos de seus próprios membros eram maiores (em termos de base social e poder político) do que a coalizáo, o que fazia com que as posiçóes deles náo fossem decididas prioritariamente no âmbito daquela arena (REBRIP, 2007). Grandes organizaçóes, como a CUT ou o Movimento dos Trabalhadores Rurais Sem Terra (MST), viam a REBRIP como um espaço importante para acessar conhecimento, permitir coordenaçáo de açóes em torno de objetivos e questóes específicas, e debater com outros tipos de atores com os quais não se encontravam necessariamente fora da coalizáo - mas náo como uma arena para construir posiçóes comuns vinculantes. Assim, embora a REBRIP tenha sido capaz de sustentar altos níveis de participação, sua capacidade de desempenhar o papel da representaçáo enfrentou limitaçóes importantes e crescentes com o tempo. ${ }^{20}$

Paradoxalmente, o baixo perfil adotado pela REBRIP implicou que fosse mais bem sucedida do que sua homóloga mexicana. Tal e como Diani $(2003,2013)$ tem argumentado, brokers náo são necessariamente lideranças fortes, pois desempenhar esse papel em cenários de ação coletiva heterogêneos pode solapar as chances de se agir como mediador entre diferentes facçóes e organizaçóes.

$\mathrm{Na}$ medida em que os conglomerados associativos que deveriam cumprir papéis institucionalizados de intermediação foram progressivamente substituídos por laços diretos, como ocorreu na RMALC, colocou-se em xeque toda a estrutura de intermediaçáo institucionalizada de coalizóes que cruza e conecta as escalas continental, nacional e local. Ao mesmo tempo, a proliferaçáo de vínculos diretos também sugere um processo potencialmente positivo de diversificação e fortalecimento das relaçóes, e náo necessariamente uma tendência dos atores a se afastar da açáo coletiva transnacional e da construçáo sustentada de coalizóes.

20 Para uma análise mais detalhada, ver von Bülow (20II). 


\section{Associações pico e entidades multissetoriais}

No Brasil e no México pós-transição, uma ampla gama de associaçóes dedicadas ao desenvolvimento local, à defesa de direitos e à assistência social tem enfrentado o desafio de criar formas organizacionais inovadoras para desempenhar papéis de intermediaçáo internos e externos. Os nomes locais variam: "fóruns", "centrales", "redes”, "federaçôes", "coordenadoras", "ONGs" (que trabalham para outras ONGs) e "fundaçôes" (que trabalham para associaçóes).

De acordo com a tipologia de brokers institucionalizados proposta, fóruns e redes constituem casos de entidades multissetoriais, enquanto que os centros, as federaçóes, as coordenadoras e as ONGs e fundaçóes (que trabalham para outras organizaçóes) são associaçóes pico. No caso das entidades multissetoriais, atores diversificados estiveram envolvidos em sua fundaçáo: ONGs de defesa de causas, associaçóes sem fins lucrativos voltadas à prestação de serviços e comprometidas com a assistência social, associaçóes de bairro e organizaçóes de movimentos populares. No caso das associaçôes pico, principalmente a partir dos anos 1990, as ONGs foram importantes, embora outros atores também tenham estado envolvidos na sua fundaçáo (GURZA LAVALLE; HOUTZAGER; CASTELLO, 2011).

\section{I Organizações de organizações, fóruns e afins na Cidade do México e em São Paulo}

No México, novas formas de associaçóes pico começaram a aparecer no cenário de mobilização social da década de 1970, quando o movimento das classes baixas urbanas, conhecido como Movimiento Popular Urbano (MUP), estava à frente dos protestos sociais. ${ }^{21}$ Além das frentes populares, surgiram iniciativas mais estáveis e duradouras em torno do MUP. Elas expressavam a força de atores do MUP em níveis nacional e metropolitano. Por exemplo, a Coordinadora Nacional del Movimiento Urbano Popular (CONAMUP) se destacou no MUP graças à sua capacidade de convocar a população de segmentos mal-aquinhoados e promover a ação unificada com atores

21 Estes são novos, não só porque eram atores emergentes na década de 1970, mas em comparação com as organizações mais importantes criadas pelo movimento operário no país, na década de 1930, como parte do acordo do Estado corporativista mexicano que fundiu corporações, atores sociais organizados e partido de Estado. 
diversificados e em todo o país (RAMÍREZ, 1988; ISUNZA, 2001, p. 179284; ALVAREZ, 2005, p. 158). A CONAMUP e a maioria das associaçóes pico do MUP decaíram no final da década de 1980 e no início da década de 1990 (BOLOS, 1999, p. 166).

Formas renovadas de associaçóes pico surgiram novamente a partir dos anos 1990, engajando-se na transiçáo democrática, na capacitaçáo da sociedade civil e na defesa de direitos. Alguns exemplos sáo, Convergencia, Red Regional para la Migración, Red Nacional de Organizaciones Civiles de Derechos Humanos (Red TDT) e Alianza Mexicana de Organizaciones Sociales (AMOS). Essas associaçóes já se encontravam entre os atores mais centrais da sociedade civil em meados da década de 2000 (GURZA LAVALLE; BUENO, 2011). Um pequeno número delas tinha perfis temáticos estreitos, trabalhando com públicos muito específicos, mas a maioria trabalhava com causas amplas, como liberdade sexual e direitos reprodutivos, direitos civis e humanos, e democratizaçáo, ou para apoiar grupos em condiçóes de vulnerabilidade. Associaçóes pico que trabalhavam com o primeiro conjunto de causas amplas foram fundadas principalmente por ONGs de defesa de direitos, enquanto aquelas dedicadas a trabalhar com segmentos vulneráveis foram criadas principalmente por organizaçóes sem fins lucrativos envolvidas na assistência social e por organizaçóes da sociedade civil que visavam a defesa de valores familiares e cristáos.

No Brasil, grupos de organizaçóes da sociedade civil pertencentes ao que foi chamado de "nova sociedade civil" e "novo sindicalismo" também criaram associaçóes pico. Trataremos apenas do primeiro grupo, muitas vezes chamado de ONGs. A literatura geralmente tem considerado este grupo como intensamente engajado no trabalho em rede (networking) e na coordenação da definiçáo de agendas entre atores da sociedade civil (CASANOVAS; GARCÍA, 1999, p. 69-74; SCHERER-WARREN, 1996). O fato de as ONGs terem sido a referência para a descrição das associaçóes pico na literatura não é acidental: há associaçóes pico influentes que têm grande visibilidade e trabalham exclusivamente para ONGs. Em outras palavras, essas organizaçóes de intermediaçáo expressam o aumento da densidade e importância das ONGs - por exemplo, a Associaçáo Brasileira de Organizaçóes Náo Governamentais (ABONG). 
A ABONG conta com mais de 230 ONGs filiadas, espalhadas por todas as regiōes brasileiras. Além de ser uma organizaçáo juridicamente fundada por outras organizaçóes, seus critérios políticos de pertencimento sáo claros. A ABONG define-se como "democrática, pluralista, antirracista e antissexista, que congrega organizaçóes que lutam contra todas as formas de discriminação, de desigualdade, pela construçáo de modos sustentáveis de vida e pela radicalização da democracia". ${ }^{22}$ É particularmente sintomático de seu perfil de associaçáo pico que na reunião plenária em que foi legalmente instituída, em 1991, tenha sido recusada, de forma unânime, a afiliaçáo de uma entidade engajada na planificação familiar (e náo na defesa de direitos reprodutivos) (NOGUEIRA, 2014, p. 179-181). ${ }^{23}$ A ABONG realiza programas para facilitar a construçáo de alianças entre atores sociais, promover a reforma política, aumentar a influência política da sociedade civil em questóes como políticas urbanas, políticas sociais e participaçáo, e representa seus membros no debate e aprovaçáo de leis - especialmente quando se trata de leis que regulam o terceiro setor. No entanto, ao contrário das associaçóes pico da Cidade do México, em São Paulo, este tipo de broker foi fundado por um espectro maior de atores, desde associaçóes de bairro, como é o caso da Confederaçáo Nacional de Associaçóes de Moradores (CONAM), até atores da sociedade civil relacionados ao mercado e à responsabilidade social corporativa, como no caso do Grupo de Institutos, Fundaçōes e Empresas (GIFE).

Assim como na Cidade do México, associaçóes pico da "nova sociedade civil" com sede em São Paulo também estavam entre os atores mais centrais em meados dos anos 2000. ${ }^{24}$ Essas associaçóes trabalham na defesa de direitos e na reivindicaçáo de questóes distributivas e de acesso a serviços, como as demandas de ONGs feministas e de associaçóes de bairro. Elas também se congregam em torno de afinidades ideológicas e têm um perfil programático mais claro do que o encontrado na capital mexicana. Especificamente, estáo ligadas a redes de ONGs de esquerda - ou, na denominaçáo nativa, do "campo

22 Veja a autodefinição em ww.abong.org.br, (visitado em 10 de dezembro, 20।3). Veja também o Estatuto da ABONG, disponivel em: <http://abong.org.br/quem_somos.php?id=3>.

23 Bem-Estar Familiar - Bemfam é o nome da entidade que teve sua afiliação à ABONG recusada (NOGUEIRA, 2004, p. 180).

24 A centralidade das associações foi aferida como a média de determinadas medidas de centralidade para este tipo em comparação com a média das mesmas medidas para outros tipos de atores. 
democrático popular" -, a fundaçóes de financiamento do terceiro setor e a redes de base religiosa ou vinculadas à Igreja católica. Essas três redes não só conectam diferentes conjuntos de atores e seus brokers, mas também representam pontos de vista diferentes e, de alguma forma, opostos sobre o sentido da ação coletiva - respectivamente, o engajamento na mudança social de políticas, instituiçóes e valores sociais; na corresponsabilidade, empreendedorismo e ação conjunta com o setor público; e na assistência e apoio a populaçóes vulneráveis. Assim, a principal diferença entre as duas cidades é que uma gama mais ampla de atores, mesmo os periféricos, como associaçóes de bairro, conseguiu criar associaçóes pico em Sáo Paulo.

Do ponto de vista da institucionalização da intermediação e seus desafios, há semelhanças relevantes entre as associaçóes pico de ambas as metrópoles. Os limites à filiação muitas vezes não são táo formais como postula de modo puro a tipologia, mas esses brokers apresentam, sim, definiçóes claras de pertencimento e foram fundados por outras organizaçóes para coordenar suas açóes, construir agendas comuns, aumentar sua capacidade de agregar interesses e, é claro, para promover os interesses de seus fundadores e representá-los diante de outros atores - principalmente da sociedade civil e do Estado. Curiosamente, à medida que se especializam em intermediação para seus fundadores, em ambos os contextos elas têm poucas relaçóes com outras associaçóes pico (são heterófilas, na linguagem da análise de redes) (GURZA LAVALLE; BUENO, 2011).

Ter posiçóes centrais nas redes de ecologias organizacionais ampliadas mexicana e paulista implica vantagens para obter e transmitir informaçóes e outros recursos materiais e simbólicos, e permite a influência sobre um amplo conjunto de atores (GURZA LAVALLE; CASTELLO; BICHIR, 2008). A centralidade dessas associaçóes pico é estrutural ou baseada em sua posiçáo nas redes da sociedade civil; portanto, não diz muito sobre as maneiras como essas vantagens posicionais são efetivamente utilizadas por diferentes associaçóes. No entanto, mostra que a institucionalização das organizaçóes de intermediação teve êxito na criação de atores posicionados favoravelmente para cumprir os papéis de intermediaçáo que se espera desempenhem. Embora nấo existam números nem conhecimento acumulado sobre fracassos ou taxas de mortalidade de organizaçóes da sociedade civil, as posiçóes na rede são importantes. 
O sucesso coloca a questáo dos riscos associados à concentraçấo dos recursos voltada a aumentar a efetividade interna e externa. Uma característica interessante dessas associaçóes pico é que elas parecem minimizar os trade-offs da efetividade ao estreitar a gama de interesses, valores e opinióes a ser levados em conta. Em outras palavras, fortes afinidades ideológicas e entendimentos programáticos comuns sobre o significado da açáo coletiva implicam escolher atores semelhantes que estejam dispostos a tomar o caminho da institucionalização. Por causa de tais afinidades substantivas, as associaçóes pico trabalham com conjunto conhecido de preferências. Portanto, o espaço para divergências de vulto sobre programas e projetos a serem realizados é menor, embora à custa da diversidade. ${ }^{25}$

As ecologias organizacionais ampliadas representam desafios de intermediaçáo náo só para os atores que compartilham valores - os quais poderiam optar pela criaçáo de associaçóes pico -, mas também para conjuntos mais heterogêneos de organizaçóes civis. Associações com características, valores e interesses diversos, por vezes, veem benefícios em algum grau de coordenaçáo entre si, o que tem gerado uma infinidade de fóruns no Brasil, cujo perfil corresponde claramente ao das entidades multissetoriais. Fóruns são espaços relativamente abertos, destinados a promover debate sobre prioridades e orientaçóes gerais para políticas entre atores com foco temático compartilhado, mas sem contar necessariamente com interesses substantivos convergentes. Assim, fóruns costumam ser organizados em torno de áreas de políticas, por exemplo, o Fórum Saúde, o Fórum do Idoso, o Fórum HIV/AIDS, o Fórum de Reciclagem, e atores organizacionais e individuais interessados na área podem participar, independentemente de suas características organizacionais e, dentro de certos limites, de sua ideologia. Assim, ao contrário das associaçóes pico analisadas anteriormente, o mesmo fórum pode englobar como membros ativos associaçóes de bairro, organizaçóes sem fins lucrativos, prestadoras de serviços e comprometidas com a assistência social, ONGs de defesa de direitos, organizaçóes dos movimentos populares ou associaçóes de autoajuda.

25 A coincidência de posições substantivas pode alterar a natureza das divergências e não necessariamente eliminá-las. Compartilhar valores substantivos pode reduzir conflitos em relação a prioridades gerais, mas aumentar a intensidade das divergências sobre escolhas especícias dentro das questões valorizadas. Essa é uma possibilidade lógica e, nesta seção, estamos explorando as implicações de características encontradas empiricamente. 
Tais associações podem participar do mesmo espaço discutindo questóes relacionadas a políticas públicas específicas, mesmo que alimentem entendimentos substantivos diferentes sobre o papel da açáo coletiva ou da política em questão.

Os fóruns são fundados e apoiados por organizaçóes civis, e normalmente têm apenas participação ocasional - se tiverem - de autoridades do Estado. Essas entidades multissetoriais náo impóem nem monitoram o cumprimento das resoluçóes que resultam de suas deliberaçóes, mas tais resoluçóes funcionam como diretrizes tanto para membros quanto para apoiadores náo participantes. Além disso, os fóruns sáo extremamente heterogêneos e náo seletivos, e têm pouca relaçáo entre si. Essas características sáo relevantes, uma vez que expressam seu papel como espaços destinados a possibilitar a deliberaçấo entre atores com interesses temáticos gerais compartilhados. No primeiro semestre de 2000, os fóruns náo estavam entre os atores mais centrais dentro das redes da sociedade civil em São Paulo, mas tampouco eram atores periféricos. Em vez disso, eles ocupavam uma posição de centralidade média, conectando diferentes tipos de atores que de outra forma náo estariam relacionados entre si, enquanto eram secundários na estratégia de relacionamento (networking) de quase todos os atores.

$\mathrm{Na}$ ecologia organizacional mexicana, existem entidades multissetoriais como os fóruns - por exemplo, Fórum das Migraçôes -, mas elas nẫo sâo comuns e, surpreendentemente, encontram-se poucas mençóes a elas na literatura (CESCO, 2007, p. 34; ÁLVAREZ, 2000, p. 182; COLOUMB; DUHAU, 1997, p. 176). Utilizando outros nomes, e com números reduzidos, algumas entidades multissetoriais atuam principalmente como facilitadoras do diálogo entre atores envolvidos com questóes semelhantes por exemplo, o Consorcio para el Diálogo Parlamentario y la Equidad de Género, fundado por organizaçóes da sociedade civil e que visa a facilitar a comunicaçáo entre os atores do movimento feminista e parlamentares, ou a Coalición Mexicana por la Corte Penal Internacional, criada por organizaçóes da sociedade civil e acadêmicos para promover debates e conscientizaçấo sobre o Tribunal Penal Internacional.

Os fóruns de São Paulo e, em muito menor grau, as entidades multissetoriais mexicanas, apresentam algumas características interessantes do ponto de vista dos papéis de intermediaçáo e os desafios a eles associados. 
Normalmente, não desenvolvem uma agenda para agir por conta própria, mas permitem o adensamento vagaroso de consensos entre participantes no médio e longo prazos, e definiçóes mínimas de prioridades no curto prazo. Eles desempenham um importante papel de reforçar a construção de redes entre seus membros, compartilhando informaçóes e possibilitando a deliberação entre grupos muito diferentes de atores. Assim, não surpreendentemente, os fóruns estâo ligados à mais diversa gama de atores dentro da ecologia organizacional ampliada paulistana, bem como são, de longe, o tipo de ator que tem menos laços com atores de sua própria espécie (na linguagem de redes, constituem o tipo de organizaçáo civil mais heterófilo encontrado nos dois contextos).

Em suma, essas entidades multissetoriais brasileiras e mexicanas trabalham com organizaçóes da sociedade civil agrupadas por afinidade temática, atuando como facilitadoras do diálogo e como espaços para reunião e coordenaçáo periódica, com mínimas restriçóes à entrada de atores. Em princípio, tal pluralidade de atores deveria aumentar os riscos de se atingir efetividade, mas estes brokers reduzem-nos ao minimizar o escopo e o alcance das tarefas de intermediaçáo executadas. Em outras palavras, eles fornecem meios para a construçáo de consensos, mas contam com pouca margem de manobra - se houver alguma - para agir por conta própria e, ainda menos, para fazer cumprir esse consenso.

\section{Comentários finais: intermediação institucionalizada, um empreendimento arriscado}

Em contextos de ecologias organizacionais ampliadas, como os $\mathrm{da}$ pós-transiçáo na América Latina, formas institucionalizadas de intermediação criadas por organizaçôes da sociedade civil têm se tornado cada vez mais comuns e relevantes, mas ainda recebem pouca atençáo sistemática. $\mathrm{Na}$ literatura de movimentos sociais, a intermediaçáo foi conceituada de forma estreita como um mecanismo relacional que produz efeitos positivos para a mobilizaçáo, desencadeada por atores que ocupam posiçóes específicas e cumprem papéis informais de conexáo. No entanto, como dissemos, os impactos da intermediação são contingentes, e nâo inerentemente bons ou ruins para a disseminação da mobilização social ou para a promoção dos interesses dos atores sujeitos à intermediaçáo. Além disso, a intermediaçáo pode ser institucionalizada, e muitas vezes é. Pressupor a horizontalidade das redes da 
sociedade civil, como acontece muitas vezes na literatura sobre movimentos sociais e sociedade civil na América Latina, torna a intermediação uma função difusa da própria rede, esvaziando os desafios de intermediaçáo, para náo falar das relaçóes de poder.

A institucionalizaçáo da intermediação não é um "caminho natural" ou espontâneo, mas uma decisão política consciente tomada por atores diante de desafios de intermediaçáo. Ela náo deve ser vista como uma decisáo simples, principalmente porque, para elevar as expectativas de efetividade interna e externa, os atores devem contar com consenso interno sobre como lidar com os trade-offs da efetividade. Na verdade, levando-se em consideraçáo os custos e as dificuldades de criar e manter organizaçóes de intermediaçáo, sua proliferação pode ser considerada como um indicador de densidade da sociedade civil e de sua capacidade para a ação. Os casos das ecologias organizacionais ampliadas mexicana e paulistana sugerem que a segunda conta com atores com maiores capacidades de ação.

A análise dos casos empíricos dos conglomerados associativos - REBRIP e RMALC - mostra que, de fato, é imenso o desafio de manter papéis de intermediação ao longo do tempo entre conjuntos heterogêneos de atores, e entre estes e atores externos. Estas duas coligaçóes apresentam dois resultados diferentes. No caso da RMALC, a capacidade de cumprir papéis de intermediação foi se tornando cada vez mais restrita ao longo do tempo; a REBRIP, por sua vez, foi capaz de executar um conjunto mais amplo de tarefas. No entanto, em ambos os casos, o papel de representante foi o mais difícil de sustentar ao longo do tempo e o primeiro a estar sob suspeita quando os membros começaram a levantar críticas. A representaçáo é o papel mais arriscado da escada da intermediaçáo, já que pode implicar decisóes de cumprimento obrigatório, ao passo que a tradução oferece riscos menores.

A análise das associaçóes pico e entidades multissetoriais da Cidade do México e de São Paulo sugere que os riscos associados à intermediação institucionalizada podem ser compensados não só no plano do comportamento dos atores individuais, como mostra o desenho institucional da REBRIP, mas também no plano agregado da composição das ecologias organizacionais. Nos casos de associaçóes pico, a homogeneidade entre os membros reduz a diversidade interna de interesses e facilita o cumprimento de papéis de intermediação internos e externos, mas à custa da pluralidade. Considerando-se que as 
ecologias organizacionais ampliadas aumentam a interdependência em relação a novas constelaçóes de atores, a coordenaçáo foi alcançada em Sáo Paulo pela criaçáo de entidades multissetoriais (fóruns) abertas a atores muito diferentes, mas que não têm capacidade de impor decisóes vinculantes. Curiosamente, o caso da REBRIP mostra que, no nível micro, pode ocorrer efeito compensatório semelhante ao que foi encontrado no nível da ecologia organizacional, pois atores específicos podem se relacionar de forma diferente com o mesmo broker. Isso levanta uma questão crucial: quem é intermediado pelo broker? A institucionalizaçáo da intermediaçáo trabalha interna e externamente em níveis agregados, mas, no plano micro, cada ator tem sua própria agenda.

Este artigo contribui para a literatura organizacional sobre movimentos sociais e sociedade civil ao lançar luz sobre os papéis e trade-offs e tipos de intermediação institucionalizada que organizaçôes civis desempenham em ecologias organizacionais ampliadas. Também propóe uma agenda de pesquisa. É necessário fazer mais análise empírica dos papéis de intermediação internos e externos desempenhados por diferentes tipos de brokers institucionalizados para se entender como atores superam - ou náo - os riscos da intermediaçáo e as vantagens e desvantagens que lhes sáo inerentes em contextos históricos específicos.

\section{Referências}

ÁLVAREZ, L. E. Distrito Federal: sociedad, economía, política y cultura. México: CIICH/ UNAM, 2005.

ÁlVAREZ, L.; ZICCARDI, A. Organizaciones Sociales. In: GARZA, G. (Org.). La Ciudad de México en el fin del segundo milenio (Distrito Federal: El Colegio de México y Gobierno del Distrito Federal), 2000. p. 684-689.

AHRNE, G.; BRUNSSON, N. Meta-organizations. Northampton: Edward Elgar Publishing, 2008. ARNSTEIN, S. A ladder of citizen participation. Journal of the American Planning Association, v. 35 , n. 4 , p. 216-24, 1969.

AUYERO, J. Performing Evita: a tale of two peronist women. Journal of ontemporary Ethnography, v. 27, n. 4, p. 461-493, 1999a.

Re-membering peronism: an ethnographic account of the relational character of political memory. Qualitative Sociology, v. 22, n. 4, p. 331-351, 1999b. 
AVRITZER, L. Um desenho institucional para o novo associativismo. Lua Nova, n. 39, p. 149$174,1997$.

BOLOS, S. Constitución de actores sociales y la política. México: Universidad Iberoamericana/ Plaza and Valdez Editores, 1999.

BURT, R. S. Structural holes: the social structure of competition. Cambridge: Harvard University Press, 1992.

Brokerage and closure: an introduction to social capital. Oxford: Oxford University Press, 2005.

CASANOVAS, R. S.; CHACÓN, O. G. Las ONGs latinoamericanas y los desafíos del desarrollo organizacional. Bolívia: ICCO/PROACTIVA/IDEPRO, 2000.

COLLIER, R.; HANDLIN, S. Introduction: popular representation in the interest arena. In: COLLIER, R.; HANDLIN, S. (Org.). Reorganizing popular politics: participation and the new interest regime in Latin America. University Park: The University of Pennsylvania University Press, 2009. p. 3-31.

COLOUMB, R.; DUHAU, E. Dinámica urbana y procesos socio-políticos. México: Ocim, CENVI, UAM, 1997. v. II, p. 139-173.

DAHL, R. A. A democratic dilemma: system effectiveness versus citizen participation. Political Science Quarterly, v. 109, n. 1, p. 23-34, Spring 1994.

DE LA GARZA TOLEDO, E. El corporativismo: teoría y transformación. Revista Iztapalapa, n. 34, p. 11-28, jul./dez. 1994.

DIANI, M. Mapping contentious fields in Latin America. In: GRASA, R.; MARTÍ, S. (Org.) Polarización y conflictos en América Latina. Barcelona: Editorial Bellaterra. No prelo. Brokerage. In: SNOW, D.; DELLA PORTA, D.; KLANDERMANS, B.; McADAM, D. (Ed.). The Wiley-Blackwell Encyclopedia of Social and Political Movements. Malden: Blackwell Publishing, 2013.

Leaders or brokers? In: DIANI, M.; McADAM, D. (Ed.). Social movements and networks. Oxford: Oxford University Press, 2003. p. 105-122.

FERNANDEZ, R. M.; McADAM, D. Social networks and social movements: multiorganizational fields and recruitment to Mississippi Freedom Summer. Sociological Forum, v. 3, n. 3, p. 357-82, 1988. FORMENT, C. Democracy in Latin America, 1760-1900: civic selfhood and public life in Mexico and Peru. Chicago: The University of Chicago Press, 2003. 
GAY, R. The broker and the thief: a parable (reflections on popular politics in Brazil). LusoBrazilian Review, v. 36, n. 1, p. 49-70, Summer 1999.

GOULD, R. Power and social structure in community elites. Social Forces, v. 68, n. 2, 1989.

GOULD, R.; FERNANDEZ, R. M. Structures of mediation: a formal approach to brokerage in transaction networks. Sociological Methodology, v. 19, p. 89-126, 1989.

GURZA LAVAllE, A.; CASTELLO, G.; BICHIR, R. Protagonistas na Sociedade civil: redes e centralidades de organizaçóes civis em São Paulo. Dados: Revista de Ciências Sociais, v. 50, n. 3, p. 465-498, 2007.

Atores periféricos na sociedade civil: redes e centralidades de organizaçóes em São Paulo.

Revista Brasileira de Ciências Sociais, v. 23, n. 68, p. 73-96, out. 2008.

GURZA LAVALLE, A.; BUENO, N. Waves of change within civil society in Latin America: Mexico City and São Paulo. Politics \& Society, v. 39, n.3, p. 415-450, sept. 2011.

GURZA LAVALLE, A.; HOUTZAGER, P.; CASTELLO, G. A construção política das sociedades civis. In: GURZA LAVALLE, A. (Org.). O horizonte da política: questóes emergentes e agendas de pesquisa. São Paulo: UNESP, 2012. p. 185-259.

GURZA LAVALLE, A.; ZAREMBERG, G. Más allá de la representación y del clientelismo: hacia un lenguaje de la intermediación política. Revista Mexicana de Ciencias Políticas y Sociales, Nueva Época, año LIX, n. 221, p. 19-50, mayo-agosto 2014.

GURZA LAVALLE, A.; VON BÜLOW, M. Institutionalized brokers and collective actors: different types, similar challenges. In: ROSSI, F.; VON BÜLOW, M. (Org.). Social movement dynamics: new perspectives on theory and research from Latin America. Ashgate Press. No prelo.

HANDLIN, S.; KAPISZEWSKI, D. Three forms of scaling: embeddedness, nodal NGOs, and flexible fronts. In: COLLIER, R.; HANDLIN, S. (Org.). Reorganizing popular politics: participation and the new interest regime in Latin America. University Park: The University of Pennsylvania University Press, 2009. p. 230-259.

HANNAN, M.; FREEMAN, J. Organizational ecology. Cambridge: Harvard University Press, 1989.

HANNAN, M.; PÓLOS, L.; CARROL, G. Logics of organizations theory: audiences, codes and ecologies. Princeton: Princeton University Press, 2007.

HARPER, D. Online etymology dictionary. 2014. Disponível em: $\leq$ http://www.etymonline. com/index.php?term=broker>. Acesso em: 5 abr. 2014 . 
HIRSCHMAN, A. O. Exit, voice, and loyalty: responses to decline in firms, organizations, and States. Cambridge: Harvard University Press, 1970.

ISUNZA, E. Las tramas del alba: una visón de las luchas por el reconocimiento en el México contemporáneo (1968-1993). México: Porrua/CIESAS, 2001.

KLANDERMANS, B.; OEGEMA, D. Potentials, Networks, Motivations and Barriers: Steps Towards Participation in Social Movements. American Sociological Review, v. 52, p. 519-31, 1987.

LEVITSKY, S. An "organised disorganisation": informal organisation and the persistence of local party structures in argentine peronism. Journal of Latin American Studies, v. 33, p. 29-65, 2001.

MALLOY, J. Authoritarianism and corporatism in Latin America. University of Pittsburg Press, 1977.

MARSDEN, P. V. Brokerage behavior in restricted exchange networks. In: MARSDEN, P. V.; LIN, N. (Org.). Social structure and network analysis. Beverly Hills: Sage, 1982. p. 201-218.

MASSICOTTE, M. J. Mexican sociopolitical movements and transnational networking in the context of economic integration in the Americas. Dissertaçáo não publicada - Department of Political Science, York University, 2004.

McADAM, D.; TARROW, S.; TILLY, C. Dynamics of contention. Cambridge: Cambridge University Press, 2001.

MICHELS, R. [1911]. Political parties: a sociological study of the oligarchical tendencies of modern democracy. Kitchener: Batoche Books, 2001.

MISCHE, A. Partisan publics: communication and contention across Brazilian youth activist networks. Princeton/Oxford: Princeton University Press, 2008.

MORRIS, A. Black southern student sit-in movement: an analysis of internal organization. American Sociological Review, v. 46, n. 6, p. 744-767, 1981.

NOGUEIRA, do A. F. Gestáo da relação entre associaçáo e associados: três casos brasileiros. 2014. PhD dissertation theses - Escola de Administraçáo de Empresas de Sáo Paulo, Fundaçáo Getúlio Vargas, São Paulo, 2014.

PAPEP/UNDP. Los conflictos sociales en América Latina. La Paz: PAPEP/UNDP; UNIRBolivia, 2011.

RAMÍREZ, J. M. S. Trabajador y/o colono, ¿una dicotomía en las luchas sociales? (La articulación entre el movimiento urbano popular y el sindicalismo independiente). In: ALONSO, J. (Org.). Los movimientos sociales en el Valle de México. México: Ediciones de la Casa Chata, 1988. v. II, p. 21-99. 
REBRIP - Rede Brasileira pela Integraçáo dos Povos. Balanço do período 2005-2007: roteiro para avaliaçáo e debate. Rio de Janeiro, 2007. Mimeografado.

ROSSI, F; VON BÜLOW, M. (Org.). Social movement dynamics: new perspectives on theory and research from Latin America. Ashgate Press. No prelo.

SCHERRER-WARREN, I. Redes de movimentos sociais. São Paulo: Loyola, 1996.

SCHMITTER, P. Interest conflict and political change in Brazil. California: Stanford University Press, 1971.

. Still the century of corporatism? The Review of Politics, v. 36, n. 1, p. 85-131, jan. 1974. The consolidation of democracy and representation of social groups. American Behavioral Scientist, v. 35, p. 422-449, 1992.

SILVA, E. Challenging neoliberalism in Latin America. Cambridge: Cambridge University Press, 2009.

SKOCPOL, T. Protecting soldiers and mothers: the political origins of social policy in the United States. Cambridge: Harvard University Press, 1992.

SNOW, D. A.; ZURCHER, L. A.; EKLAND-OLSON, S. Social networks and social movements: a microstructural approach to differential recruitment. American Sociological Review, v. 45, p. 787-801, 1980 .

STOVEL, K.; SHAW, L. Brokerage. Annu. Rev. Sociol, v. 38, p. 139-158, 2012.

VASI, I. V. Brokerage, miscibility, and the spread of contention. Mobilization: an International Quarterly, v. 16, n. 10, 2011.

VON BÜLOW, M. Building transnational networks: civil society and the politics of trade in the Americas. Cambridge: Cambridge University Press, 2010.

Brokers in action: transnational coalitions and trade agreements in the Americas. Mobilization, v. 16, n. 2, p. 165-180, 2011.

A batalha do livre comércio: a construção de redes transnacionais da sociedade civil nas Américas. São Paulo: Editora Unesp, 2014.

WARREN, M. What kind of civil society is best for democracy? Portuguese Journal of Social Science, v. 3, n. 1, p. 37-47, 2004. 


\section{Civil society and institutionalized brokerage: different brokers, similar dilemmas}

\section{Abstract}

Intermediation is inherent in social mobilization because coordination among mobilized actors cannot be reached without either informal or institutionalized brokers. However, literature has paid little attention to institutionalized brokerage within civil society. This article analyzes on conceptual grounds different intermediation roles played by organizations among civil society actors and between them and other state and market actors. The article develops a definition and a typology of such brokers aiming at shedding light on both different modes of institutionalized brokerage and efficiency-autonomy trade-offs related to founding organizational brokers. Drawing on previous research findings, we apply the typology to Mexican and Brazilian civil society brokers and analyze the trade-offs along time.

Keywords: broker, brokerage, civil society, social movements, Brazil, Mexico 